\section{Comparison of factors associated with leukemia and lymphoma mortality in Brazil}

\author{
Comparação de fatores associados com a \\ mortalidade por leucemia e linfoma no Brasil
}

Comparación de factores asociados a la
mortalidad por leucemia y linfoma en Brasil
Marcela de Sá Gouveia 1

Jessica Keyla Matos Batista 1

Taciana Silveira Passos 1

Beatriz Santana Prado 1

Carlos Eduardo Siqueira 2

Marcos Antonio Almeida-Santos 1,3

\begin{abstract}
In the last decades, few epidemiological studies have discussed the mortality rates due to leukemia and lymphoma in Brazil. This study analyzes the evolution over time of the number of deaths due to leukemia and lymphoma in Brazil, between 2010 and 2016, considering the population's characteristics and spatial distribution. This is a retrospective epidemiological study based on data obtained in the Brazilian Health Informatics Department (DATASUS), associated with the quantitative population. We created choropleth maps and predictive models of mortality rates, using the incidence rate ratio (IRR) to measure the size of the effect. Leukemia had a 1.76 higher mortality rate than lymphoma. Leukemia mortality trends increased by $1.2 \%$ per year between 2010 and 2016. Regions with the lowest social inequality had higher mortality rates for both diseases. There was a difference between peaks with higher chances of death due to leukemia (> 60 years) and lymphoma (> 70 years). Older age, male, white, and South and Southeast regions were associated with higher mortality by leukemia or lymphoma.
\end{abstract}

Lymphoma; Leukemia; Epidemiologic Studies; Mortality Registries

\author{
Correspondence \\ M. A. Almeida-Santos \\ Universidade Tiradentes. \\ Av. Murilo Dantas 300, Aracaju, SE 49032-490, Brasil. \\ marcosalmeida2010@yahoo.com.br \\ 1 Universidade Tiradentes, Aracaju, Brasil. \\ 2 University of Massachusetts Boston, Boston, U.S.A. \\ 3 Tiradentes Institute, University of Massachusetts Boston, \\ Boston, U.S.A.
}




\section{Introduction}

Cancer is the second leading cause of death in the world and may be responsible for about 9.6 million deaths in 2018 1. According to data released by the World Health Organization (WHO), 8.8 million people die of this disease yearly, with $70 \%$ of these deaths occurring in emerging countries and lower income per capita 2. The number of cancer deaths in Brazil increased by 31\%, from 152,000 in 2000 to 223,400 in 2015 . The estimate for the 2018-2019 biennium indicated that 600,000 new cancer cases are expected to occur each year, placing it among the countries with the highest cancer incidence in the world 3.

Despite increasing efforts toward screening and early diagnosis, risk factors associated with the development of malignant neoplasms are strongly present in the world and the Brazilian population 4 . Approximately $33 \%$ of cancer deaths worldwide derive from nine potentially changeable risk factors of relevant participation in both high-income and middle- and low-income countries 5 . Between $30 \%$ and $50 \%$ of cancer deaths could be prevented by modifying or mitigating key risk factors 6 .

Leukemia and lymphoma represent $6.1 \%$ of the causes of population mortality from cancer ${ }^{1}$. Of this, $3.2 \%$ corresponds to leukemia and $2.9 \%$ to lymphoma. These malignant neoplasms constitute a heterogeneous category of diseases that affect the hematopoietic and lymphoproliferative tissue 7. The first affects the proliferation and accumulation of neoplastic cells of bone marrow and blood in several stages of cell differentiation, subdivided by clinical practice into five major prevalent subtypes in the world population: acute lymphoblastic leukemia, acute myeloid leukemia, acute monocytic leukemia, acute erythremia and erythroleukemia, unspecified cell type acute leukemia 8 . The second comprises a group of cancers that originate in the lymphatic system, subdivided into two main types: Hodgkin's lymphoma and non-Hodgkin's lymphoma 9.

In the world ranking, leukemia occupies the 15 th position for the most incident malignant tumors and the 10th place for mortality. Non-Hodgkin's lymphoma, the most prevalent subtype, ranks 13th on incidence and the 11th regarding the number of deaths 2 . The estimates of new cases in Brazil are, respectively, 10,800 for leukemia and 12,710 for lymphoma 3 .

In the global and national scenario, cancer is a complex public health issue because of its progressive epidemiological, social, and economic impact 10,11. In 2012, the Brazilian cost of cancer death was around USD 53,400 and an approximate 1.2 million years of productive life was lost 12 .

The literature highlights some common risk factors for the development of leukemia and lymphoma, such as: genetic predisposition, advanced age, exposure to pesticides and solvents, previous contact with ionizing radiation and use of immunosuppressive drugs. The importance of preexisting myelodysplastic syndromes as an additional risk factor for leukemia and of HIV, Epstein-Barr and HTLV-1 infections for lymphoma is highlighted 13,14,15,16,17,18.

Most previous studies on the number of deaths from leukemia and lymphoma have divided them into their subtypes, without considering the wide variation in prognosis and trends between similar cell line diseases or maturation stage. For public health purposes, though, it is best to group them according to the categories defined by the International Classification of Diseases - 10th revision (ICD-10) to investigate the general profile of the disease.

In the last decades, few epidemiological studies have discussed the mortality rates due to leukemia and lymphoma in Brazil, by the analysis of temporal trend 19,20,21 and spatial distribution 22 . We also found no study that uses predictive models to contemplate the mortality rates of the two diseases comparatively, throughout several years.

This study aimed to analyze, retrospectively, the evolution over time of the number of deaths due to leukemia and lymphoma in Brazil, between 2010 and 2016, considering the characteristics of the population regarding gender, age, color and, particularly, its spatial distribution. 


\section{Material and methods}

This retrospective study compiled data from the Health Informatics Department (DATASUS) database of the Brazilian Ministry of Health (http://www2.datasus.gov.br/DATASUS/index.php?area=02, accessed on 25/Jun/2018).

We selected the period between 2010 and 2016 for analysis due to higher reliability in more recent data analyzes. There has been a progressive improvement in the database by technological advances, and these are the most recent data made available by the Ministry of Health information system on the subject.

We collected leukemia and lymphoma mortality data by vital statistics available in the area of health information. The number of deaths, according to the ICD-10, was filtered by categories according to the following variables: state, including the capital Brasília as a Federal District; age group; color; year and gender. The variable age group comprised individuals under one year old and over 80 years old as the pathology incidence increases with the aging process, turning the onset of leukemia in childhood and adolescence significant. We included categories C81 to C85 and C91 to C95 of ICD-10 for lymphoma and leukemia, respectively.

Spatial distribution analysis might be used in ecological studies interested in identifying the distribution of morbidity or mortality among the population 23 . Spatial analysis processes treat geographic data that has a geographic location expressed as coordinates on a map and descriptive attributes which can be represented in a conventional database. We obtained the geospatial data from the Brazilian population through the Demographic Census of 2010 (https://ww2.ibge.gov.br/home/estatistica/ populacao/censo2010/default.shtm, accessed on 20/Jul/2018) and the inter-census projections of the Brazilian Institute of Geography and Statistics - IBGE (non-census years) (https://www.ibge.gov. br/estatisticas-novoportal/sociais/populacao/9103\%20estimativas-de-popula-?=\&amp\%3Bt=down loads\&gt, accessed on 20/Jul/2018).

\section{Statistical analysis}

We present categorical variables in absolute numbers and percentages, and continuous variables as mean and standard deviation. We calculated the mortality rate according to the number of deaths and the estimated population in each year (using IBGE data) per 100,000 inhabitants. Choropleth maps were generated according to quartiles of mortality rates.

The predictive models of mortality rates elaborated used as dependent variable the number of deaths. We used the population size for each year and state to adjust the "exposure" for the death count, in models of proportional intensity. We selected the most appropriate model using three criteria: overdispersion identification; convergence of algorithms in less than 100 iterations; lower Akaike (AIC) and Bayesian (BIC) values 24,25.

For estimating overdispersion, we used the Pearson dispersion statistics. When relevant, we calculated robust Huber-White estimates for obtaining the standard error. We compared the Poisson model with two types of negative binomial regression: type I, keeping the constant dispersion parameter, and type II, using the quadratic term.

We used the incidence rate ratio (IRR) to measure the size of the effect. All coefficients had a 95\% confidence interval $(95 \% \mathrm{CI})$ calculated. We considered as criteria of statistical significance value of two-tailed $\mathrm{p}<0.05$. Calculations were performed in Stata software, version 15.1 (https://www. stata.com).

\section{Ethical aspects}

The study precluded an informed consent form because it used public data, with no elements of identification of the individuals studied. 


\section{Results}

Between 2010 and 2016, Brazil recorded 68,769 deaths from leukemia (9,824 deaths/year \pm 543) and 49,753 deaths from lymphoma (7,108 deaths/year \pm 370$)$. In this period, deaths due to leukemia predominated in males (53.72\%) and white (57.24\%); and similar for lymphoma deaths, with male predominance $(55.09 \%)$ and white $(61.93 \%)$.

Using the IBGE population estimates for each year and state, we calculated the average number of deaths per 100,000 inhabitants associated with leukemia and lymphoma between 2010 and 2016. The State of Rio Grande do Sul obtained the highest number of deaths associated with leukemia or lymphoma in all years: the highest value of 4.66 in 2016 and the lowest of 4.18 in 2013. The state with the lowest averages of deaths was Amapá, except for the years 2013 and 2015, when the State of Roraima contributed to the lowest rates (Table 1). The rates per capitals revealed values higher than the rates per state.

The analysis by regions in the chosen period varied in death rates due to leukemia or lymphoma: North (1.53); Northeast (2.21); Central (2.59); Southeast (3.01) and South (3.02) (Figure 1). According to the Gini index, the South and Southeast regions have lower levels of inequality compared with the other regions. Also, the FIRJAN Municipal Development Index (IFDM) reveals that the most developed cities are concentrated in these regions 26 .

Table 1

Mean of deaths associated with leukemia or lymphoma per 100,000 inhabitants in Brazil, per state between 2010 and 2016.

\begin{tabular}{|c|c|c|c|c|c|c|c|}
\hline State & 2010 & 2011 & 2012 & 2013 & 2014 & 2015 & 2016 \\
\hline Acre & 0.95 & 1.54 & 1.71 & 2.06 & 2.15 & 1.37 & 2.33 \\
\hline Alagoas & 1.47 & 1.53 & 1.64 & 1.71 & 1.82 & 1.51 & 1.93 \\
\hline Amapá & 0.37 & 0.73 & 1.00 & 1.29 & 1.00 & 1.17 & 1.28 \\
\hline Amazonas & 1.46 & 1.82 & 1.96 & 1.96 & 1.52 & 1.74 & 1.89 \\
\hline Bahia & 1.73 & 1.68 & 2.03 & 1.73 & 1.92 & 1.92 & 2.04 \\
\hline Ceará & 2.22 & 2.33 & 2.46 & 2.31 & 2.46 & 2.55 & 2.43 \\
\hline Espírito Santo & 2.65 & 2.85 & 2.82 & 2.76 & 2.62 & 2.39 & 2.94 \\
\hline Federal District & 3.74 & 3.58 & 3.51 & 3.55 & 3.77 & 3.65 & 3.44 \\
\hline Goiás & 2.14 & 2.01 & 2.29 & 2.32 & 2.44 & 2.40 & 2.28 \\
\hline Maranhão & 1.13 & 1.44 & 1.39 & 1.32 & 1.45 & 1.54 & 1.52 \\
\hline Mato Grosso & 1.61 & 1.80 & 2.26 & 1.74 & 2.06 & 2.16 & 2.18 \\
\hline Mato Grosso do Sul & 2.41 & 2.26 & 2.83 & 2.61 & 2.40 & 2.39 & 2.65 \\
\hline Minas Gerais & 2.53 & 2.61 & 2.61 & 2.67 & 2.72 & 2.83 & 2.82 \\
\hline Pará & 1.38 & 1.42 & 1.61 & 1.39 & 1.47 & 1.63 & 1.54 \\
\hline Paraíba & 2.28 & 1.99 & 2.48 & 2.27 & 2.31 & 2.29 & 2.39 \\
\hline Paraná & 3.24 & 3.30 & 3.83 & 3.26 & 3.38 & 3.37 & 3.39 \\
\hline Pernambuco & 2.32 & 2.50 & 2.31 & 2.38 & 2.42 & 2.58 & 2.37 \\
\hline Piauí & 2.74 & 2.66 & 2.75 & 2.46 & 2.89 & 2.71 & 3.28 \\
\hline Rio de Janeiro & 3.12 & 3.45 & 3.36 & 3.14 & 3.11 & 3.21 & 3.14 \\
\hline Rio Grande do Norte & 2.35 & 2.73 & 3.00 & 2.89 & 3.15 & 2.85 & 3.12 \\
\hline Rio Grande do Sul & 4.30 & 4.63 & 4.57 & 4.18 & 4.22 & 4.56 & 4.66 \\
\hline Rondônia & 1.44 & 1.14 & 1.79 & 1.36 & 1.66 & 1.33 & 1.76 \\
\hline Roraima & 1.00 & 1.52 & 1.28 & 1.23 & 1.71 & 0.99 & 1.65 \\
\hline Santa Catarina & 3.01 & 3.10 & 3.05 & 3.13 & 3.11 & 3.53 & 3.44 \\
\hline São Paulo & 3.41 & 3.44 & 3.42 & 3.33 & 3.32 & 3.50 & 3.69 \\
\hline Sergipe & 2.17 & 1.94 & 2.13 & 2.09 & 2.21 & 2.47 & 2.49 \\
\hline Tocantins & 1.63 & 1.18 & 2.12 & 1.99 & 2.07 & 1.98 & 1.43 \\
\hline
\end{tabular}




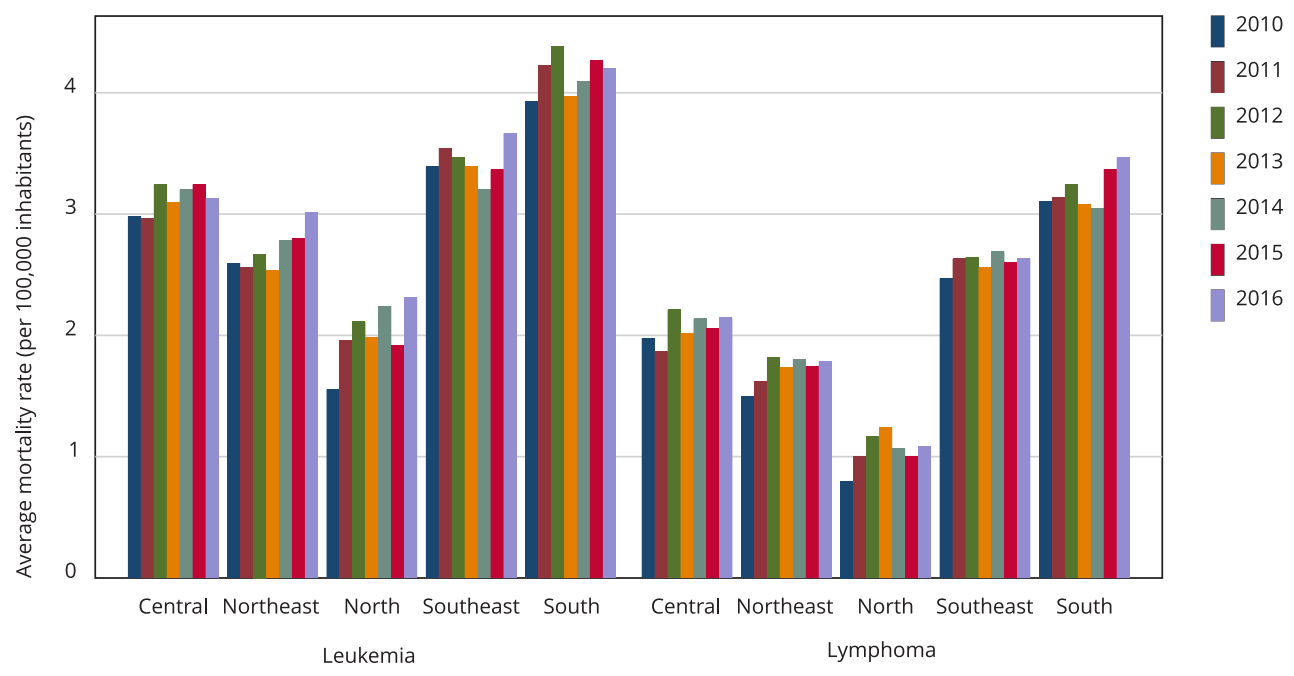

The South region obtained the highest average death rate for both diseases during the study period, with 3.38\% of deaths associated with leukemia in 2012, and lower values until 2016. On the other hand, the mean number of deaths associated to lymphoma in the southern region increased gradually between 2014, 2015 and 2016, with values of 3.04\%, 3.37\%, and 3.46\%, respectively.

Quarte-stratified choropleth maps (Figures 2 and 3 ) show that the highest quartile for populationadjusted mortality rate associated with leukemia and lymphoma occurred in the South region in 2016. The maps illustrate the predominance of leukemia in São Paulo, Piauí, and Rio Grande do Norte (Figure 2); and lymphoma in São Paulo, Rio de Janeiro, and Federal District (Figure 3).

Lower mortality rates associated with leukemia occurred in most northern states: Roraima, Amapá, Pará, Tocantins, and Rondônia. Maranhão and Bahia, located in the Northeast region, are also included. For lymphoma, the North region also showed the lowest rates, except Acre, which is in the second highest quartile, alongside Maranhão.

Predictive models of mortality rate were elaborated using the number of deaths as dependent variable. The Poisson model presented a Pearson dispersion statistic over 4, indicating significant overdispersion. The best fit model was the negative binomial type II regression with robust HuberWhite estimates for standard error.

Overall, males have a $30 \%$ higher chance of mortality due to leukemia or lymphoma. When compared with black and brown individuals, whites showed mortality around 7.7 to 9.1 times higher, respectively. The South and Southeast regions presented higher probabilities than the Central, North and Northeast regions. There was a slight tendency to mortality rate increase between 2010 and 2016, lower than $1 \%$ per year, reaching maximum value in sexagenarians (Table 2).

The main difference between the models is the highest increase in the risk of death regarding age in patients with lymphoma. For each increase in age - adjusting for gender, color, region, exposed population and year - the risk of death from lymphoma becomes about 15 times higher than that from leukemia. Besides, the peak for greatest chance of death due to leukemia occurred in septuagenarians, whereas for lymphoma the peak was verified for sexagenarians.

Compared with lymphomas and adjusted for the other factors, leukemia presents a 1.76 higher mortality rate (Table 2). We also found a slight trend of leukemia mortality growth around $1.2 \%$ per year between 2010 and 2016, which did not occur in patients with lymphoma. 
Figure 2

Choropleth map of Brazil, referring to deaths per 100,000 inhabitants associated with leukemia, in 2016.

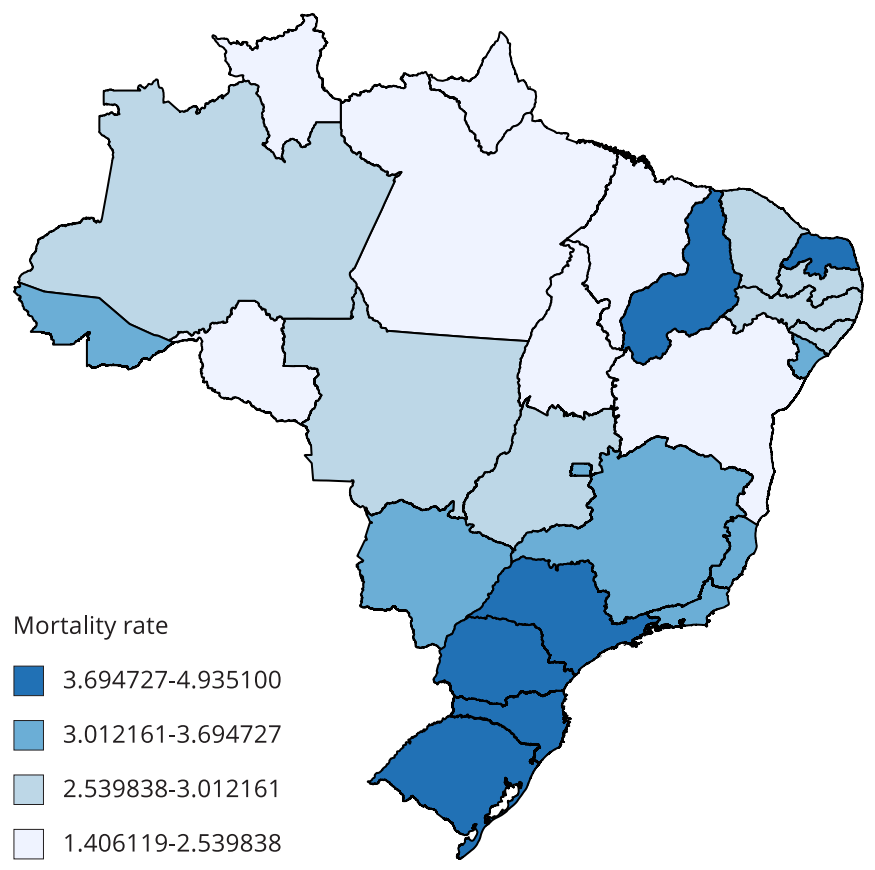

\section{Figure 3}

Choropleth map of Brazil, referring to deaths per 100,000 inhabitants associated with lymphoma, in 2016.

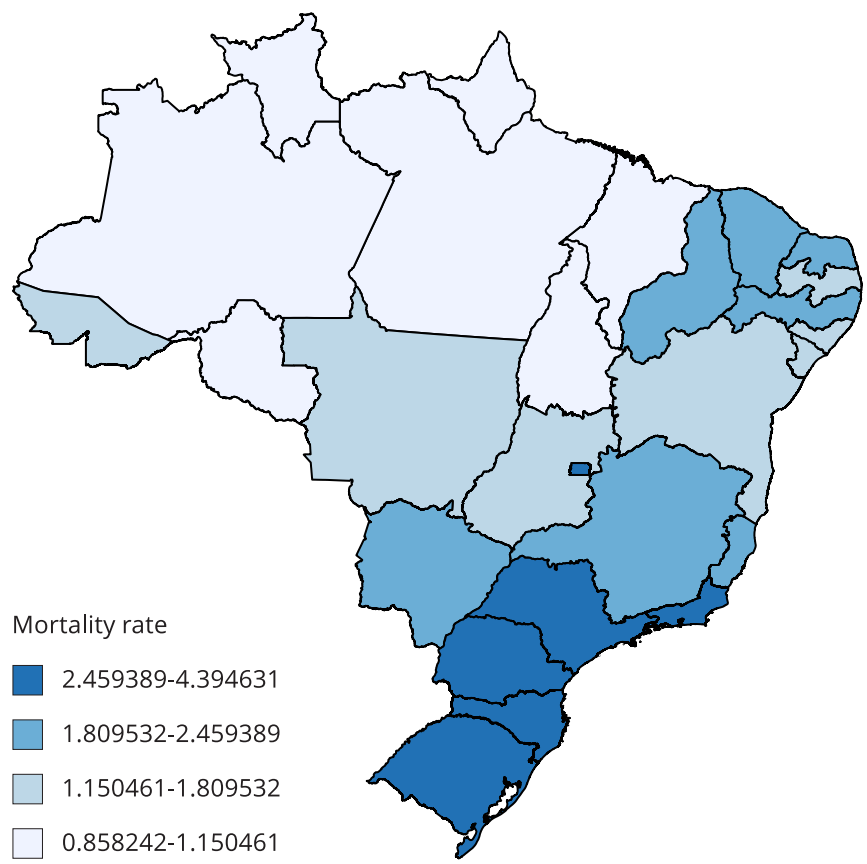


Table 2

Longitudinal analysis with a negative binomial model, having as dependent variable the number of deaths associated with factors adjusted for the estimated annual population for each Brazilian state between 2010 and 2016.

\begin{tabular}{|c|c|c|c|c|c|c|c|c|c|}
\hline & \multicolumn{3}{|c|}{ Leukemia } & \multicolumn{3}{|c|}{ Lymphoma } & \multicolumn{3}{|c|}{ Leukemia + lymphoma } \\
\hline & IRR & $95 \% \mathrm{Cl}$ & p-value & IRR & $95 \% \mathrm{Cl}$ & p-value & IRR & $95 \% \mathrm{Cl}$ & p-value \\
\hline \multicolumn{10}{|l|}{ Age groups (years) } \\
\hline < 1 (reference) & - & - & - & - & - & - & - & - & - \\
\hline $1-4$ & 7.20 & $6.25-8.31$ & $<0.0001$ & 15.22 & $5.42-42.77$ & $<0.0001$ & 7.38 & $6.36-8.57$ & $<0.0001$ \\
\hline $5-9$ & 8.59 & $7.45-9.92$ & $<0.0001$ & 22.14 & 7.94-61.75 & $<0.0001$ & 9.02 & $7.78-10.46$ & $<0.0001$ \\
\hline $10-14$ & 9.15 & $7.45-9.92$ & $<0.0001$ & 35.28 & $12.66-98.29$ & $<0.0001$ & 10.35 & 8.95-11.97 & $<0.0001$ \\
\hline $15-19$ & 9.76 & $8.51-11.20$ & $<0.0001$ & 65.81 & $12.66-98.29$ & $<0.0001$ & 12.69 & $11.02-14.62$ & $<0.0001$ \\
\hline $20-29$ & 16.75 & $8.51-11.20$ & $<0.0001$ & 195.36 & $70.36-542.45$ & $<0.0001$ & 26.50 & $23.09-30.42$ & $<0.0001$ \\
\hline $30-39$ & 16.49 & $14.42-18.85$ & $<0.0001$ & 232.73 & 83.84-646.07 & $<0.0001$ & 28.49 & $24.83-32.69$ & $<0.0001$ \\
\hline $40-49$ & 18.35 & $16.06-20.95$ & $<0.0001$ & 287.17 & 103.47-797.03 & $<0.0001$ & 33.34 & $29.08-38.23$ & $<0.0001$ \\
\hline $50-59$ & 25.27 & $22.15-28.83$ & $<0.0001$ & 452.44 & 103.47-797.03 & $<0.0001$ & 49.33 & $43.05-56.54$ & $<0.0001$ \\
\hline $60-69$ & 32.70 & $22.15-28.83$ & $<0.0001$ & 621.34 & $223.88-1724.43$ & $<0.0001$ & 65.84 & $57.48-75.42$ & $<0.0001$ \\
\hline $70-79$ & 33.19 & $22.15-28.83$ & $<0.0001$ & 608.13 & 219.14-1687.59 & $<0.0001$ & 65.43 & $57.13-74.94$ & $<0.0001$ \\
\hline$\geq 80$ & 26.65 & 23.37-30.39 & $<0.0001$ & 380.17 & 136.93-1055.54 & $<0.0001$ & 45.94 & $40.05-52.69$ & $<0.0001$ \\
\hline \multicolumn{10}{|l|}{ Gender } \\
\hline Female (reference) & - & - & - & - & - & - & - & - & - \\
\hline Male & 1.23 & $1.19-1.28$ & $<0.0001$ & 1.40 & 136.93-1055.54 & $<0.0001$ & 1.30 & $1.27-1.34$ & $<0.0001$ \\
\hline \multicolumn{10}{|l|}{ Color } \\
\hline Black (reference) & - & - & - & - & - & - & & - & - \\
\hline White & 8.72 & $8.32-9.14$ & $<0.0001$ & 9.46 & $8.92-10.04$ & $<0.0001$ & 9.10 & $8.77-9.45$ & $<0.0001$ \\
\hline Brown & 7.95 & $7.56-8.37$ & $<0.0001$ & 7.19 & $6.75-7.67$ & $<0.0001$ & 7.73 & $7.42-8.05$ & $<0.0001$ \\
\hline Yellow & 0.08 & 0.07-0.09 & $<0.0001$ & 0.11 & $0.09-0.12$ & $<0.0001$ & 0.09 & $0.08-0.10$ & $<0.0001$ \\
\hline Indigenous & 0.04 & $0.03-0.05$ & $<0.0001$ & 0.02 & $0.02-0.03$ & $<0.0001$ & 0.03 & $0.03-0.04$ & $<0.0001$ \\
\hline \multicolumn{10}{|l|}{ Region } \\
\hline North (reference) & - & - & - & - & - & - & - & - & - \\
\hline Central & 1.28 & $1.21-1.37$ & $<0.0001$ & 1.62 & $1.49-1.75$ & $<0.0001$ & 1.39 & $1.31-1.43$ & $<0.0001$ \\
\hline Northeast & 1.33 & $1.25-1.40$ & $<0.0001$ & 1.74 & $1.61-1.87$ & $<0.0001$ & 1.46 & $1.39-1.53$ & $<0.0001$ \\
\hline Southeast & 1.39 & $1.31-1.47$ & $<0.0001$ & 2.09 & $1.93-2.25$ & $<0.0001$ & 1.62 & $1.54-1.70$ & $<0.0001$ \\
\hline South & 1.52 & $1.41-1.64$ & $<0.0001$ & 2.32 & $2.12-2.55$ & $<0.0001$ & 1.78 & $1.67-1.89$ & $<0.0001$ \\
\hline Year & 1.01 & $1.00-1.02$ & 0.0006 & 1.01 & $1.00-1.02$ & 0.157 & 1.01 & $1.00-1.02$ & 0.0006 \\
\hline \multicolumn{10}{|l|}{ Neoplasm } \\
\hline Lymphoma (reference) & - & - & - & - & - & - & - & - & - \\
\hline Leukemia & - & - & - & - & - & - & 1.76 & $1.72-1.81$ & $<0.0001$ \\
\hline
\end{tabular}

95\%Cl: 95\% confidence interval; IRR: incidence rate ratio.

The predictive model showed no statistically significant difference in the incidence rate of deaths from lymphoma in the period studied when adjusted for the other factors. Older age, male, white, and South and Southeast regions were the variables associated with higher mortality in the period studied, both for leukemia and lymphoma. 


\section{Discussion}

Cancer mortality is increasing worldwide. The reasons reflect both aging and population growth, as well as changes in the incidence and distribution of major cancer risk factors, and socioeconomic development. For leukemia and lymphoma, incidence rates are nearly twice as high in countries with high and very high Human Development Index (HDI) compared to those with medium and low HDI. However, the differences in mortality between these regions are lower, partly due to higher lethality in countries with a lower HDI 2.

Since 2015 Brazil has an HDI of 0.754 , considered high by the United Nations 27 , even with social inequality as its main problem. The Gini index measures inequality and its distribution, with values ranging from 0 (equality) to 1 (maximum inequality). In 2017, the Gini index of real average monthly household income per capita in Brazil was 0.549. The South (0.473) and Southeast (0.529) had the lowest inequalities, and the Central (0.536), North (0.544) and Northeast (0.567), the largest 28 .

Similarly, the 2016 data on employment and income, health and education of the Brazilian municipalities of the IFDM revealed that of the 100 most developed cities in Brazil, 58 are in São Paulo, southeastern Brazil, while North and Northeast cities concentrate the country's worst socioeconomic indicators 26 .

The present analysis of leukemia and lymphoma mortality trends in Brazil found varied death rates among regions, with regions of lower inequality showing higher death rates for both diseases. Different from leukemia, the largest quartile for lymphoma deaths appeared in the six states with the best living conditions in Brazil until 2015: São Paulo (0.846), Santa Catarina (0.827), Federal District (0.825), Rio Grande do Sul (0.781), Paraná (0.768) and Rio de Janeiro (0.752). Among the last ranking states was Piauí, one of the states featured in the largest quartile of leukemia deaths. These data confirm the latest evaluation of the State Management Challenges Index (DGE) 29.

There was a wide difference amongst regions. For example, we found a higher number of deaths in the most industrialized regions, as well as those with less inequality. The South and Southeast regions concentrate most cases, which may be associated with the presence of treatment referral centers, population lifestyle and exposure to risk factors 19.

The strong relationship between the development of lymphoid neoplasms and the use of chemical agents may explain these results. Farming is an important sector of Brazilian economy and its maintenance and production employ extensive plantation areas, transgenic seeds and chemical inputs, such as fertilizers and pesticides, giving the country the title of largest consumer of pesticides in the world 30 .

In 2014, the International Agency for Research on Cancer (IARC) identified 27 occupational agents and six exposure circumstances as potentially carcinogenic in humans 31 . Of the more than 100 carcinogens identified by the IARC, approximately $25 \%$ contribute to leukemia or lymphomas 32. Regarding environmental risk factors, Brazil presents an intense agricultural activity. Exposure to toxic chemicals (so-called pesticides) in regions of medium and high agricultural production appears as a potential causal factor for these cancers, since IARC classifies agrochemicals frequently used in Brazilian crops, such as glyphosate, as potentially carcinogenic 33.

Paraná, Rio Grande do Sul, Santa Catarina, and São Paulo represent the largest quartile in the two-choropleth maps presented. They integrate the ten states with a high level of consumption of pesticides in Brazil, occupying the 2nd, 3rd, 4th, and 10th places, respectively 34. São Paulo also concentrates large industrial poles emitters of carcinogens substances such as benzene, which is an important cause of acute myeloid leukemia and suspected of causing other leukemias and nonHodgkin's lymphoma 22,35.

The highest increase of the mortality rate attributed to the capitals, if compared with the respective states, is probably due to the concentration of oncology services, since each capital represents a hub of up-level health care and assistance. We must also consider that the data collected in the medical records come mostly from self-reported information - due to the lack of specialized services in the countryside, some individuals declare as residential address that of family members or support houses located in the capitals ${ }^{36}$. This result may also be due to cancer transition: locations with higher socioeconomic development have higher incidence of cancers associated with westernization of habits and lifestyle, and exposure to environmental factors due to urbanization and industrialization 37. 
Changes in the evolution of mortality rates reflect changes in exposure to environmental and lifestyle risk factors, as well as improvements in diagnosing, treating, verifying, and certifying deaths. But these changes may occur asymmetrically, explaining the differences found in the evolution of mortality rates in the Brazilian regions.

The South region, for instance, presented the highest average death rate of the two diseases in the period, with a decline in leukemia and an increase in lymphoma in recent years. According to data from the Brazilian National Cancer Institute (INCA), mortality rates due to neoplasms have a high chance of reduction if cancer detection and treatment are performed early in the disease 38 .

As in developed countries, the less unequal regions of Brazil, through better availability and health care, enable a healthier aging pattern in the population, and aging is one of the main risk factors to leukemia and lymphoma. The better quality of the health system also enables early diagnosis and, consequently, lower chances of registering the cause of death as "undefined". Poor data collection and underreporting of the Mortality Information System (SIM) in the Northeast and, especially, the North, further reinforces this geographical difference in the distribution of mortality related to chronic illnesses (https://ww2.ibge.gov.br/home/estatistica/populacao/censo2010/default.shtm, accessed on 20/Jul/2018).

Mortality rate increase due to leukemia in Brazil, from 2010 to 2016, may indicate problems in access to health services, either in treatment or diagnosis. The study CONCORD-2 showed a drop in the cumulative survival in Brazil from 72\% between 1995-1999 to 66\% between 2005-2009. In a more recent study, CONCORD-3 showed that the relative leukemia survival in Brazil was still below $70 \%$, even after adjusting for the high infant mortality scenario. The authors emphasize the lethality of childhood malignancies in low- and middle-income countries, where access and treatment drop out are major issues 39,40 .

Lymphoma, on the other hand, saw a drop in its mortality rate from 2010 to 2016 . This can be partially attributed to the investment in new therapies, in addition to socioeconomic improvements. These factors appear in other studies to justify the reduction in mortality rates in the United States and Europe 1,41,42. However, these changes may occur unevenly, explaining the differences we found in the evolution of mortality rates in the Brazilian regions.

Population aging in less unequal regions may contribute to the mortality patterns found. We may also infer a greater recognition of cases, with consequent decline of records with cause of indefinite death, unlike regions with greater inequality. Also, the South and Southeast populations have been exposed to high-level environmental risk factors.

Regarding the effect of age, the results in this study are similar to the findings of other Brazilian studies $19,20,21$ and of other countries $43,44,45,46,47$, in which there was a progressive increase in mortality rates with advancing age in both sexes, especially in individuals over 60 years of age. These findings may reflect unfavorable incidence trends in older adults, or problems in treatment decisions, which may be less effective or less used in this group 48,49 . Besides, older patients have unfavorable cytogenetic abnormalities and resistance to multiple drugs.

We found a difference between the peaks with higher chances of death due to leukemia ( $>60$ years) and lymphoma ( $>70$ years). In countries such as Brazil, the introduction of new drugs has contributed to reduce lymphoma mortality 21 . These possible survival patterns may result from this improved treatment and access to health services. In addition, leukemia is a high prevalent neoplasm in children and adolescents, and this aspect may modify its distribution pattern according to age group depending on the proportion of cases in each study 44,45,46,47,48,49,50.

Regarding gender differences, men were more susceptible to develop leukemia or lymphoma. Other Brazilian studies also revealed higher rates in males 19,20. This finding also appeared in studies in South Korea 43, the United States 44, Mexico 45, and Europe 46.

This is a well-known phenomenon and it is partly due to the lower exposure to occupational and environmental risk factors in women than men $51,52,53$. The increased risk of malignancies has been documented in pesticide-exposed farmers, workers in formaldehyde-using industries, and those exposed to dioxins. Most workers in these sectors are male, justifying the 1.4 times higher proportion of lymphoma death in this group 32,33,34,35,36.

The limitations of the present study relate to possible deficiencies in the quality of Brazilian mortality data, such as misdiagnosis, imprecise diagnoses in death certificates, deaths associated with 
unknown causes and potential mistakes in data entry. Future studies may use correction techniques for information quality and for underreporting, as suggested by some authors $54,55,56$. Another limitation is the absence of mortality data according to each ICD leukemia and lymphoma types, preventing extrapolate the findings of the whole category to each specific subtype.

\section{Conclusions}

Cancer mortality is a public health issue in all spheres of care. The rate of death due to leukemia showed a slight growth trend during the study period, and for each age increase, the adjusted risk of death from lymphoma was about 15 times higher than that for leukemia.

Older age, male, white and living in South and Southeast regions were associated with higher leukemia or lymphoma mortality. However, the peak with the highest risk of death occurred in different age groups - septuagenarians for leukemia and sexagenarians for lymphoma.

The study reflect the scarcity of data on the epidemiological profile of these malignant neoplasms among the Brazilian population. The findings of this study are highly relevant because they include geographic elements and population profile of the most affected. These data allow to redirect health actions to the areas and population groups most vulnerable.

\section{Contributors}

M. S. Gouveia, J. K. M. Batista, T. S. Passos, and B. S. Prado contributed to the study conception and design, data collection, data interpretation, manuscript writing, and final approval of the article. C. E. Siqueira contributed to the study conception and design, critical review of the article, and final approval of the article. M. A. Almeida-Santos contributed to the study conception and design, data analysis, data interpretation, critical review of the article, and final approval of the article.

\section{Additional informations}

ORCID: Marcela de Sá Gouveia (0000-0002-69150635); Jessica Keyla Matos Batista (0000-00020588-2925); Taciana Silveira Passos (0000-00025312-095X); Beatriz Santana Prado (0000-00030289-5699); Carlos Eduardo Siqueira (0000-00018993-3031); Marcos Antonio Almeida-Santos (0000-0003-0622-6257).

\section{References}

1. Bray F, Ferlay J, Soerjomataram I, Siegel R, Torre L, Jemal A. Global cancer statistics 2018: GLOBOCAN estimates of incidence and mortality worldwide for 36 cancers in 185 countries. CA Cancer J Clin 2018; 68:394-424.

2. World Health Organization. Global health observatory: the data repository. 2017. http:// www.who.int/gho/database/en (accessed on 17/Oct/2018).

3. Instituto Nacional de Câncer José Alencar Gomes da Silva. Estimativa 2018: incidência de câncer no Brasil. http://www.inca.gov.br/esti mativa/2018/estimativa-2018.pdf (accessed on 17/Sep/2018).

4. Panis C, Kawasaki AC, Pascotto CR, Justina EY, Vicentini GE, Lucio LC, et al. Revisão crítica da mortalidade por câncer usando registros hospitalares e anos potenciais de vida perdidos. Einstein (São Paulo) 2018; 16:eAO4018.

5. Danaei G, Vander Hoorn S, Lopez AD, Murray CJL, Ezzati M; Comparative Risk Assessment Collaborating Group (Cancers). Causes of cancer in the world: comparative risk assessment of nine behavioural and environmental risk factors. Lancet 2005; 366:1784-93.

6. Sabattini E, Bacci F, Sagramoso C, Pileri AS. WHO classification of tumours of haematopoietic and lymphoid tissues in 2008: an overview. Pathologica 2010; 102:83-7.

7. World Health Organization. Global health observatory: the data repository. 2019. https:// www.who.int/cancer/en/ (accessed on 10/Jan/ 2019). 
8. Centers for Disease Control and Prevention. Leukemia. https://www.cdc.gov/cancer/leu kemia/index.htm (accessed on 17/Sep/2018).

9. Centers for Disease Control and Prevention. Lymphoma. https://www.cdc.gov/can cer/lymphoma/index.htm(accessed on 16/Sep/ 2018).

10. Araújo Neto LA, Teixeira LA. De doença da civilização a problema de saúde pública: câncer, sociedade e medicina brasileira no século XX. Boletim do Museu Paraense Emílio Goeldi. Ciências Humanas 2017; 12:173-88.

11. Pearce A, Sharp L, Hanly P, Barchuk A, Bray F, Cancela MC, et al. Productivity losses due to premature mortality from cancer in Brazil, Russia, India, China, and South Africa (BRICS): a population-based comparison. Cancer Epidemiol 2018; 53:27-34.

12. Instituto Nacional de Câncer José Alencar Gomes da Silva. ABC do câncer: abordagens básicas para o controle do câncer. 2a Ed. Rio de Janeiro: Instituto Nacional de Câncer José Alencar Gomes da Silva; 2012.

13. Mwakigonja AR, Kaaya EE, Mgaya EM. Malignant lymphomas (ML) and HIV infection in Tanzania. J Exp Clin Cancer Res 2008; 27:9.

14. Karipidis KK, Benke G, Sim MR, Kauppinen T, Kricker A, Hughes AM, et al. Occupational exposure to ionizing and non-ionizing radiation and risk of non-Hodgkin lymphoma. Int Arch Occup Environ Health 2007; 80:663-70.

15. Zerbini MCN, Soares FA, Velloso EDRP, Chaufaille MLLF, Paes RP. Classificação da Organização Mundial da Saúde para os tumores dos tecidos hematopoético e linfoide, 4a edição, 2008 - principais modificações introduzidas em relação à 3a edição, 2001. Rev Assoc Med Bras 2011; 57:66-73.

16. Ministério da Saúde. Normas de vigilância à saúde dos trabalhadores expostos ao benzeno. http://bvsms.saude.gov.br/bvs/saude legis/gm/2017/matrizesconsolidacao/co mum/37581.html (accessed on 25/Mar/2019).

17. Hallek M, Cheson BD, Catovsky D, CaligarisCappio F, Dighiero G, Döhner H. et al. iwCLL guidelines for diagnosis, indications for treatment, response assessment, and supportive management of CLL. Blood 2018; 131:274561.

18. American Cancer Society. Risk factors for acute myeloid leukemia (AML). https://www. cancer.org/cancer/acute-myeloid-leukemia/ causes-risks-prevention/risk-factors.html (accessed on 30/Mar/2019).

19. Luz LL, Mattos IE. Tendência das taxas de mortalidade por linfoma não-Hodgkin na Região Sudeste do Brasil, 1980-2007. Cad Saúde Pública 2011; 27:1340-8.

20. Rêgo AV, Fonseca AD. Mortality trends from leukemia in Salvador - Brazil, 1980 to 2012. Rev Bras Cancerol 2015; 61:325-33.

21. Boccolini PM, Boccolini CS, Meyer A. Tendência de mortalidade por linfomas não Hodgkin no Brasil, 1980 a 2012. Cad Saúde Colet (Rio J.) 2015; 23:188-97.
22. Leal CHS, Wünsch FV. Mortality by industrialization-related leukemias. Rev Saúde Pública 2002; 36:400-8

23. Poole C. Ecologic analysis as outlook and method. Am J Public Health 1994; 84:715-6.

24. Akaike H. A new look at the statistical model identification. IEEE Trans Automat Contr 1974; 19:716-23.

25. Schwarz G. Estimating the dimensional of a model. Ann Stat 1978; 6:461-4.

26. Federação das Indústrias do Estado do Rio de Janeiro. Índice FIRJAN de Desenvolvimento Municipal. https://www.firjan.com.br (accessed on 07/Oct/2019).

27. Jahana S. Human development report 2016: human development for everyone. New York: United Nations Development Programme; 2016.

28. Instituto Brasileiro de Geografia e Estatística. Pesquisa Nacional por Amostra de Domicílios Contínua - PNAD Contínua. https://www. ibge.gov.br/estatisticas-novoportal/sociais/ populacao/17270-pnad-continua.html?edi $\mathrm{cao}=20635$ (accessed on 18/Sep/2018).

29. Macroplan. Desafios da gestão estadual. https://www.desafiosdosestados.com/ (accessed on 26/Sep/2018).

30. Carneiro FF, Augusto LGS, Rigotto RM, Friedrich K, Búrigo AC. Dossiê ABRASCO: um alerta sobre os impactos dos agrotóxicos na saúde. Rio de Janeiro: Escola Politécnica de Saúde Joaquim Venâncio, Fundação Oswaldo Cruz/São Paulo: Expressão Popular; 2015.

31. International Agency for Research on Cancer. A review of human carcinogens - Part F: chemical agents and related occupations. Lyon: International Agency for Research on Cancer; 2012. (IARC Monographs on the Evaluation of Carcinogenic Risks to Humans).

32. Eastmond DA, Keshava N, Sonawane B. Lymphohematopoietic cancers induced by chemicals and other agents and their implications for risk evaluation: an overview. Mutat Res Rev Mutat Res 2014; 761:40-64.

33. Guyton KZ, Loomis D, Grosse Y, El Ghissassi F, Benbrahim-Tallaa L, Guha N, et al. Carcinogenicity of tetrachlorvinphos, parathion, malathion, diazinon, and glyphosate. Lancet Oncol 2015; 16:490-1.

34. Pignati WA, Lima ANDS, Lara SSD, Correa MLM, Barbosa JR, Leão HDC, et al. Distribuição espacial do uso de agrotóxicos no Brasil: uma ferramenta para a vigilância em saúde. Ciênc Saúde Colet 2017; 22:3281-93.

35. Rêgo MA, Sousa CS, Kato M, de Carvalho AB, Loomis D, Carvalho FM. Non-Hodgkin's lymphomas and organic solvents. J Occup Environ Med 2002; 44:874-81.

36. Barbosa FDC, Costa AD, Ferreira DSC, Almeida DS, Azevedo CDB, Lemos ARD, et al. Aspectos epidemiológicos dos casos de leucemia e linfomas em jovens e adultos atendidos em hospital de referência para câncer em Belém, Estado do Pará, Amazônia, Brasil. Rev PanAmazônica Saúde 2015; 6:43-50. 
37. Bray F, Soerjomataram I. The changing global burden of cancer: transitions in human development and implications for cancer prevention and control. In: Gelband H, Jha P, Sankaranarayanan R, Horton S, editors. Cancer. Volume 3: disease control priorities. Washington DC: The International Bank for Reconstruction and Development/The World Bank; 2015. p. 23-44.

38. Instituto Nacional de Câncer José Alencar Gomes da Silva. Estimativa 2014: incidência de câncer no Brasil. Rio de Janeiro: Instituto Nacional de Câncer José Alencar Gomes da Silva; 2014.

39. Bonaventure A, Harewood R, Stiller CA, Gatta G, Clavel J, Stefan DC, et al. Worldwide comparison of survival from childhood leukaemia for 1995-2009, by subtype, age, and sex (CONCORD-2): a population-based study of individual data for 89828 children from 198 registries in 53 countries. Lancet Haematol 2017; 4:e202-17.

40. Allemani C, Matsuda T, Di Carlo V, Harewood R, Matz M, Nikšić M, et al. Global surveillance of trends in cancer survival 2000-14 (CONCORD-3): analysis of individual records for 37513025 patients diagnosed with one of 18 cancers from 322 population-based registries in 71 countries. Lancet 2019; 391:1023-75.

41. Ferlay J, Soerjomataram I, Ervik M, Dikshit R, Eser S, Mathers C. Globocan 2012. v1.0, cancer incidence and mortality worldwide. Lyon: International Agency for Research on Cancer; 2013.

42. Stewart BW, Wild CP. World cancer report: 2014. Lyon: International Agency for Research on Cancer; 2014.

43. Jung KW, Won YJ, Oh CM, Kong HJ, Lee DH, Lee KH. Cancer statistics in Korea: incidence, mortality, survival, and prevalence in 2014. Cancer Res Treat 2017; 49:292-305.

44. Siegel RL, Miller KD, Jemal A. Cancer statistics, 2017. CA Cancer J Clin 2017; 67:7-30.

45. Aldaco SF, Pérez PP, Cervantes SG, Torrecillas TL, Erazo VSAA, Cabrera GP, et al. Mortalidad por cáncer en México: actualización. Gac Mex Oncol 2018; 17:28-34.

46. Bertuccio P, Bosetti C, Malvezzi M, Levi F, Chatenoud L, Negri E, et al. Trends in mortality from leukemia in Europe: an update to 2009 and a projection to 2012. Int J Cancer 2013; 132:427-36.
47. Krok-Schoen JL, Fisher JL, Stephens JA, Mims A, Ayyappan S, Woyach JA, et al. Incidence and survival of hematological cancers among adults ages $\geq 75$ years. Cancer Med 2018; 7:3425-33.

48. Lamb BW, Sevdalis N, Benn J, Vincent C, Green JS. Multidisciplinary cancer team meeting structure and treatment decisions: a prospective correlational study. Ann Surg Oncol 2013; 20:715-22.

49. Hamaker ME, Schiphorst AH, Bokkel-Huinink D, Schaar C, Munster BC. The effect of a geriatric evaluation on treatment decisions for older cancer patients: a systematic review. Acta Oncol 2014; 53:289-96.

50. Ward E, Desantis C, Robbins A, Kohler B, Jemal A. Childhood and adolescent cancer statistics, 2014. CA Cancer J Clin 2014; 64:83-103.

51. Chiu BCH, Dave BJ, Blair A, Gapstur SM, Zahm SH, Weisenburger DD. Agricultural pesticide use and risk of $\mathrm{t}(14 ; 18)$-defined subtypes of non-Hodgkin lymphoma. Blood 2006; 108:1363-9.

52. Luo D, Zhou T, Tao Y, Feng Y, Shen X, Mei S. Exposure to organochlorine pesticides and non-Hodgkin lymphoma: a meta-analysis of observational studies. Sci Rep 2016; 6: 25768.

53. Zhang Y, Sanjose SD, Bracci PM, Morton LM, Wang R, Brennan P, et al. Personal use of hair dye and the risk of certain subtypes of nonHodgkin lymphoma. Am J Epidemiol 2008; 167:1321-31.

54. Gamarra CJ, Valente JG, Silva GA. Correction for reported cervical cancer mortality data in Brazil, 1996-2005. Rev Saúde Pública 2010; 44:629-38.

55. Gamarra CJ, Valente JG, Silva GA. Magnitude da mortalidade por câncer do colo do útero na Região Nordeste do Brasil e fatores socioeconômicos. Rev Panam Salud Pública 2010; 28:100-6.

56. Queiroz BL, Freire FHMA, Gonzaga MR, Lima EEC. Completeness of death-count coverage and adult mortality (45q15) for Brazilian states from 1980 to 2010. Rev Bras Epidemiol 2017; 20 Suppl 1:21-33. 


\section{Resumo}

Nas últimas décadas, poucos estudos epidemiológicos examinaram as taxas de mortalidade por leucemia e linfoma no Brasil. O presente estudo faz uma análise retrospectiva da evolução temporal do número de óbitos por leucemia e linfoma no Brasil entre 2010 e 2016, considerando as características e a distribuição espacial da população. $O$ estudo epidemiológico utilizou dados do Departamento de Informática do Sistema Único de Saúde (DATASUS), associados aos dados quantitativos da população. Foram elaborados mapas coropléticos e modelos preditivos de taxas de mortalidade. Utilizamos a razão de taxas de incidência (RTI) como medida do tamanho do efeito. A leucemia mostrou uma taxa de mortalidade 1,76 vez mais elevada que os linfomas. A mortalidade por leucemia aumentou 1,2\% por ano entre 2010 e 2016. As regiões com menor desigualdade social mostraram taxas de mortalidade mais altas para ambas doenças. Houve uma diferença entre os picos, com chances mais altas de morrer por leucemia (> 60 anos) e por linfoma (> 70 anos). Idade mais avançada, sexo masculino, cor branca e regiões Sul e Sudeste estiveram associados a taxas de mortalidade mais altas por leucemia ou linfoma.

Linfoma; Leucemia; Estudos Epidemiológicos; Registros de Mortalidade

\section{Resumen}

En las últimas décadas, pocos estudios epidemiológicos han analizado las tasas de mortalidad causadas por leucemia y linfoma en Brasil. Este estudio analiza, retrospectivamente, la evolución temporal del número de muertes, debidas a la leucemia y linfoma en Brasil, entre 2010 y 2016, considerando las características de la población y su distribución espacial. Este es un estudio epidemiológico, basado en los datos obtenidos del Departamento de Informática del Sistema Único de Salud (DATASUS), asociado con población cuantitativa. Se elaboraron mapas coropléticos y modelos predictivos de tasas de mortalidad. Usamos la razón de tasas de incidencia (RTI) como medida del tamaño del efecto. La leucemia tuvo una tasa de mortalidad un 1,76 mayor que los linfomas. Las tendencias de mortalidad por leucemia se incrementaron en un 1,2\% al año entre 2010 and 2016. Las regiones con la desigualdad social más baja contaron con unas tasas de mortalidad más altas en ambas enfermedades. Había una diferencia entre los picos con mayores oportunidades de muerte debido a la leucemia (> 60 años) y linfoma (> 70 años). Contar con una avanzada edad, género masculino, autodeclarado blanco y procedente de las regiones Sur y Sudeste estuvieron relacionados con una mortalidad más alta a causa de leucemia o linfoma.

Linfoma; Leucemia; Estudios Epidemiológicos; Registros de Mortalidad
Submitted on 25/Apr/2019

Final version resubmitted on 15/Oct/2019

Approved on 27/Jan/2020 